\title{
The application of biomass ashes in sewage sludge management - a SWOT analysis
}

\author{
Marta Wójcik ${ }^{1, *}$, and Feliks Stachowicz ${ }^{1}$ \\ ${ }^{1}$ Rzeszow University of Technology, Department of Materials Forming and Processing, \\ 35-959 Rzeszow Al. Powstańców Warszawy 8, Poland
}

\begin{abstract}
Biomass plays an important role amongst renewable energy sources and for this reason, it is sometimes called as "future fuel". According to different statistics, the share of biomass in renewable energy production is in excess of $50 \%$ and rising. The main disadvantage of biomass combustion in power plants is the production of combustion by-products, namely fly and bottom ash. In line with the sustainable development and waste hierarchy, biomass combustion by-products should be managed in different sectors of economy. Due to the specific properties, biomass ash might be applied as an effective reagent in sewage sludge management. This article shows the SWOT analysis (strengths, weaknesses, opportunities and threats) associated with the use of biomass combustion by-products in sewage sludge treatment. The presented analysis could constitute the initial stage in implementation of new method in a big way in treatment plants.
\end{abstract}

\section{Introduction}

Due to the increasing consumption of biomass in final energy production, the amount of generated combustion by-products is systematically growing. According to Vassilev et al. [1], the worldwide production of biomass ashes is estimated on 476 million tonnes every year. As long as coal fly ashes might be applied in many sectors of economy, biomass combustion by-products (BCBP) are relatively problematic waste. Specific physical and chemical characteristics, especially the content of alkaline elements, cause that biomass ashes do not meet requirements as an addition in cement and asphalt production. It is worth highlighting that cement production uses approximately 2 million tonnes of coal fly ashes in Poland every year. So far, the main receiver of biomass ashes is agriculture. Different references show that the use of BCBP as a fertilizer improves the growth and yielding of crops [2-4]. However the application of biomass ashes in agricultural practices constitutes only several per cent of worldwide production of ashes. For this reason, the recycling of $\mathrm{BCBP}$ in other purposes is a necessity.

Advantageous properties of biomass ashes enable their application in sewage sludge management. Research carried out by Wójcik et al. [5,6] confirmed the positive impact of $\mathrm{BCBP}$ on sewage sludge treatment, especially on sludge thickening and dewatering.

\footnotetext{
*Corresponding author: m.wojcik@prz.edu.pl
} 
Additionally, the content of alkaline elements in biomass ashes enables their application in sewage sludge higienization. However the use of combustion by-products in sewage sludge treatment on a big way demands to take into account different factors (Table 1), which determine the effectiveness and profitability of the whole investment. Taking into account the interdependence between particular factors ensures the achievement of the solution (Fig. 1).

Table 1. Factors affected on the application of biomass ashes in sewage sludge management in treatment plants.

\begin{tabular}{|c|ll|}
\hline Kind of factor & \multicolumn{1}{c|}{ Details } \\
\hline technological & $-\begin{array}{l}\text { amount and chemical characteristics of BCBP, } \\
\text { granulometric analysis of biomass ashes, } \\
\text { physical properties of biomass ashes, e.g. porosity, specific } \\
\text { surface area, density }\end{array}$ \\
\hline economical & $-\begin{array}{l}\text { location of power plant, } \\
\text { the possibility to utilize the mixture of sewage sludge and ash, } \\
\text { investment and operational costs of treatment plants associated } \\
\text { with the use of biomass ashes, } \\
\text { availability of funds dedicated to new technology }\end{array}$ \\
\hline environmental & $-\begin{array}{l}\text { influence of the mixture of sewage sludge and ash on particular } \\
\text { elements of the environment, } \\
\text { potential risk to the environment associated with the content of } \\
\text { heavy metals both in biomass ashes and sewage sludge }\end{array}$ \\
\hline social & $-\quad \begin{array}{l}\text { social acceptance concerning the use of biomass ashes in } \\
\text { sewage sludge management }\end{array}$ \\
\hline legal & - & \begin{tabular}{l} 
legal requirements (Polish law) \\
\hline
\end{tabular} \\
\hline
\end{tabular}

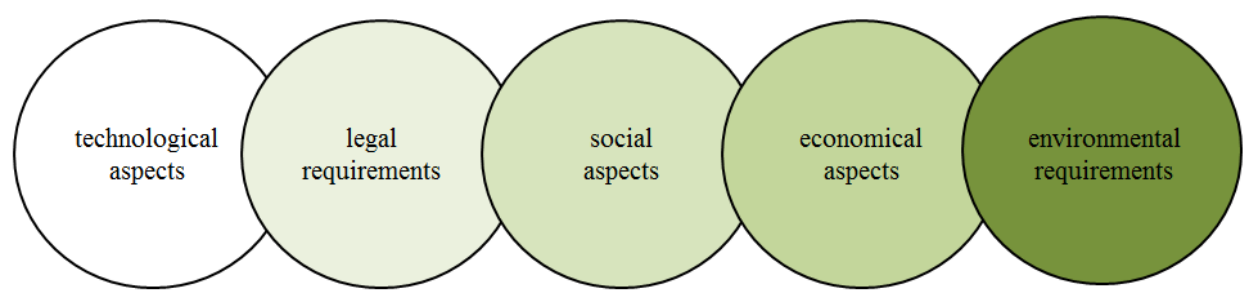

Fig. 1. Relationship between particular factors affecting on the investment.

The application of new treatment method on an industrial scale demands to prepare the SWOT analysis (strengths, weaknesses, opportunities \& threats). On the basis of the aforementioned analysis, the decision concerning the implementation of a new solution might be taken (Fig. 2). 


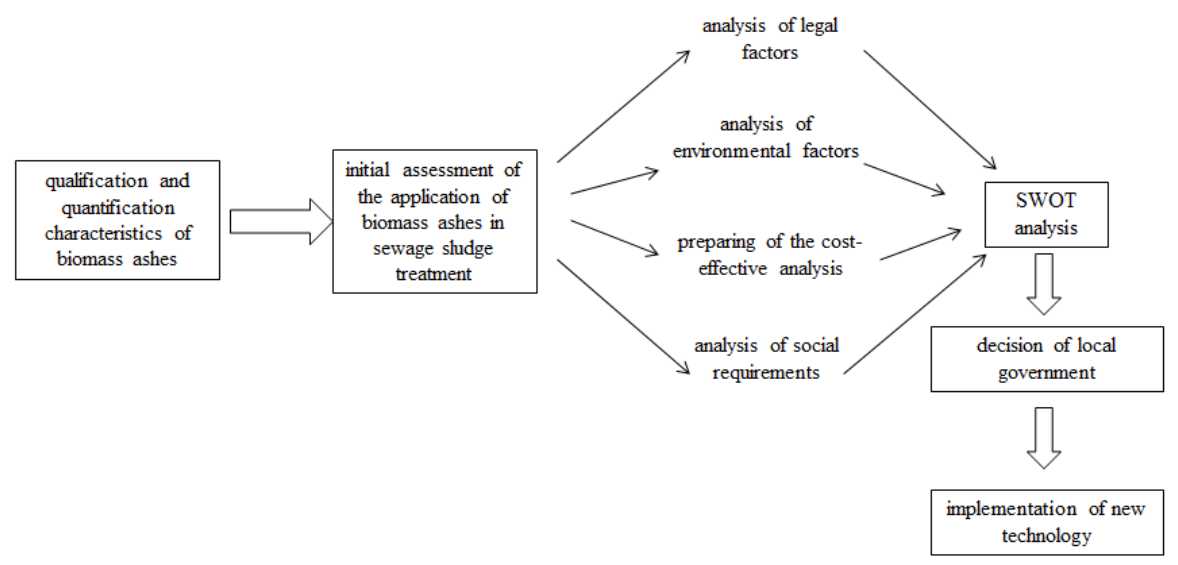

Fig. 2. Procedure of the implementation of sewage sludge treatment technology with the use of biomass ashes.

\section{Methodology}

The increasing amount of generated combustion by-products causes that the preparation of SWOT analysis associated with the application of biomass ashes in sewage sludge management is essential. The SWOT analysis included strengths, weaknesses, opportunities and treats of presented solution and was prepared on the basis of results obtained both in laboratory tests and on an industrial scale. Environmental, legal, social and economical factors were considered in presented SWOT analysis and were divided into four main categories according to the scheme below (Fig. 3).

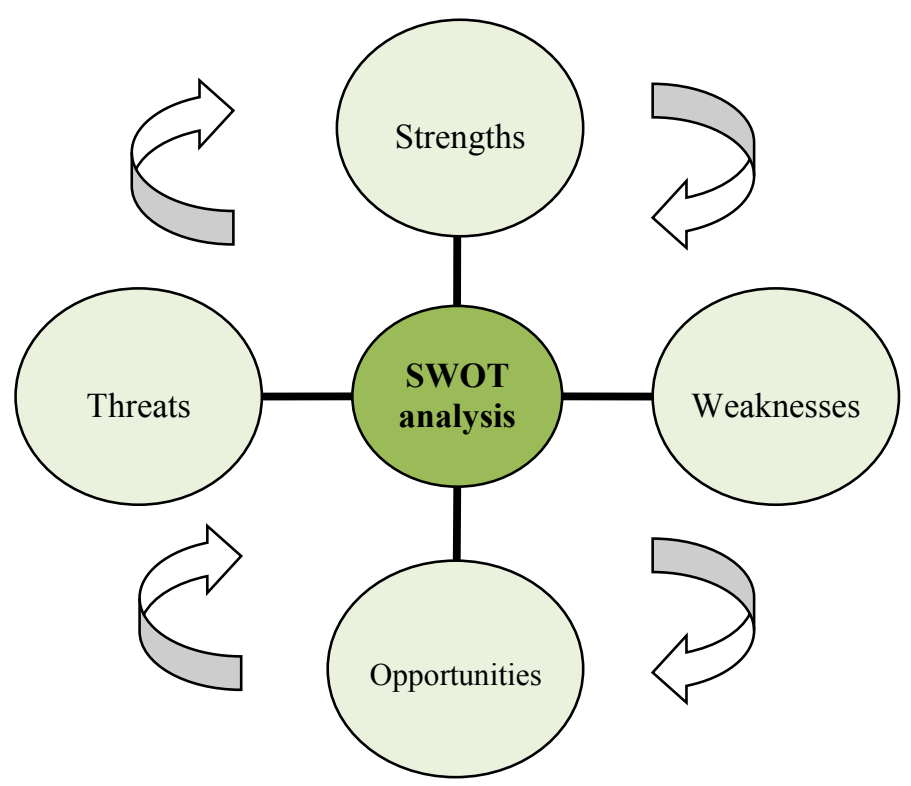

Fig. 3. The SWOT diagram. 


\section{Results}

SWOT analysis of the application of biomass ashes in sewage sludge management helps to identify both external and internal conditions that might appear during the implementation of new solution in treatment plants. The internal conditions are particularly related to strengths and weaknesses. However, the external factors refer to opportunities and threats. Detailed juxtaposition of all conditions associated with the use of BCBP is presented below (Table 2).

Table 2. SWOT analysis for the application of biomass ashes in sewage sludge treatment.

\begin{tabular}{|c|c|}
\hline Strenghts & Weaknesses \\
\hline $\begin{array}{l}\text { S1: possibility to manage biomass ashes, } \\
\text { S2: reduction or even elimination of ashes } \\
\text { landfilling } \\
\text { S3: improvement of the effectiveness of } \\
\text { sewage sludge treatment } \\
\text { S4: reduction of the use of chemical reagents } \\
\text { in treatment plants } \\
\text { S5: improvement of fertilizing properties of } \\
\text { sewage sludge } \\
\text { S6: possibility to use the mixture of sewage } \\
\text { sludge and ash in agricultural and } \\
\text { reclamation practices } \\
\text { S7: improvement of the consistence of } \\
\text { sewage sludge at convenient to further } \\
\text { application and transport } \\
\text { S8: prevalence of waste, especially in } \\
\text { industrial areas } \\
\text { S9: low costs of obtaining ashes limited to } \\
\text { the transport costs }\end{array}$ & $\begin{array}{l}\text { W1: public awareness associated with the use } \\
\text { of BCBP in treatment plants } \\
\text { W2: high profitability of investment only for } \\
\text { treatment plants located near power plants } \\
\text { W3: increase the mass of sewage sludge as } \\
\text { a result of the application of ashes } \\
\text { W4: necessity to buy new devices dedicated to } \\
\text { dosing and storage of ash in sewage sludge } \\
\text { treatment, } \\
\text { W5: requirements associated with the content } \\
\text { of heavy metals, } \\
\text { W6: need for control of the content of } \\
\text { microorganisms in the mixture of sludge and } \\
\text { ash before the application in the environment }\end{array}$ \\
\hline Opportunities & Threats \\
\hline $\begin{array}{l}\text { O1: soil quality improvement and } \\
\text { reclamation of degraded lands after the } \\
\text { application of mixture of sludge and ash } \\
\text { O2: replacement of traditional fertilizers } \\
\text { O3: development of domestic biomass } \\
\text { market } \\
\text { O4: improvement of energy security and } \\
\text { supporting the requirements associated with } \\
\text { EU climate and energy package }(3 \times 20 \%)\end{array}$ & $\begin{array}{l}\text { T1: afraid of treatment plant's leadership } \\
\text { related with the implementation of new sludge } \\
\text { treatment method } \\
\text { T2: small amount of experiments concerning } \\
\text { the influence of biomass ashes on the } \\
\text { effectiveness of sewage sludge processing. }\end{array}$ \\
\hline
\end{tabular}

\subsection{Strengths}

$\mathrm{S} 1 \& \mathrm{~S} 2$ possibility to manage $\mathrm{BCBP}$ and the reduction or even elimination of ash landfilling: As previously mentioned, the increasing share of biomass in final energy production results in the production of combustion by-products, such as fly and bottom ashes. Although biomass ashes have valuable properties which enable their application in many sectors of economy, the use of BCBP is limited by stringent standards. According to Polish standard PN-EN 197-1 [7], only silica fly ashes from coal combustion might be added to cement. Then the Polish norm PN-EN 450-1 [8] enables to apply only silica fly ash in concrete production. The impediment in applying of biomass ashes in the 
construction industry is also the high content of alkaline elements and the high losses of ignition (LOI). According to Rajczyk et al. [9], the losses of ignition for biomass ashes usually exceed $10 \%$. For ashes with a high value of LOI, Giergiczny [10] indicated the influence of unburned materials on concrete surface, what impedes the application of concrete with ash in construction and architecture. Additionally, the high value of the aforementioned parameter influences unfavourably on puzzolanic activity.

Due to the content of nutrients for plants, biomass ashes are utilized in agriculture. The literature review confirmed the positive impact of BCBP on the growth and yield of plants. But available data indicate that only $30 \%$ of generated biomass ashes are recycled in Poland every year. The low rate of recycling requires new utilization methods of biomass ashes. The use of biomass ashes in sewage sludge treatment could manage aforementioned waste in line with legal, environmental and social requirements. By means of that, the storage of BCBP might be reduced in a significant way. For this reason, the proposed solution fits into the overall principles concerning the waste hierarchy and sustainable development.

S3 \& S4 improvement of the effectiveness of sewage sludge treatment and reduction of the use of chemical reagents in treatment plants: Due to the high rate of dispersion of flocs, raw sewage sludge is characterized by low-thickening and low-dewatering capacity. In order to improve the effectiveness of sludge dewatering, chemical conditioning is commonly used. Specific properties of biomass combustion by-products are strong reasons to make them use in sewage sludge management. Biomass ash particles are incorporated in sewage sludge matrix and that is the reason why the shape, size and structure of flocs are altered [11]. It results in the improvement of sludge dewaterability. The positive impact of biomass ashes on sewage sludge treatment was confirmed by laboratory tests. Wójcik et al. $[5,6,12]$ proved that the addition of biomass ashes into sludge could improve the effectiveness of sludge dewatering even by several per cent in comparison to raw sludge.

Additionally, sewage sludge conditioning by means of biomass ashes results in the increase of $\mathrm{pH}$ of sewage sludge and the reduction of total number of bacteria. The effectiveness of biomass ashes could result in the reduction of consumption of chemical reagents in the future. By means of that, it will be possible to reduce the operational costs of treatment plants in a significant way.

S5 \& S6 possibility to use the mixture of sewage sludge and ash in agricultural practices and improvement of fertilizing properties of sewage sludge: One of the main criteria associated with the implementation of new solution on an industrial scale is the possibility of recycling of obtained product. Sewage sludge is a source of nutrients, such as: $\mathrm{N}, \mathrm{P}, \mathrm{Ca}, \mathrm{Mg}$ and microelements. Biomass ashes delivered, for example: $\mathrm{Ca}, \mathrm{Mg}, \mathrm{Na}$ and $\mathrm{K}$. The application of both sewage sludge and biomass ash enriches the soil in valuable elements as well as improves the growth and yield of plants. Kiper et al. [13] proved the positive effect of the mixture of sludge and ash on the plant's growth and the reclamation of degraded lands. Additionally, the application of the mixture of sewage sludge and biomass ash creates a closed circuit in the local ecosystem.

S7 improvement of the consistence of sewage sludge at convenient to further application and transport: The addition of biomass ashes results in the improvement of elastic properties of sewage sludge. Not only is such consistence convenient for transport and land-applying but also eliminates the danger of possible leakage of mixture. In comparison to the application of lime, the phenomenon associated with the secondary liquefaction is not observed.

S8 \& S9 prevalence of waste and low costs of obtaining ashes: The use of biomass ashes in sewage sludge management is supported by the fact that BCBP is relatively easy-obtained materials and occurs in large amount, especially in industrial areas. 


\subsection{Weaknesses}

W1 public awareness associated with the use of BCBP in treatment plants: The addition of biomass ashes into sewage sludge and further application of obtained mixture in agricultural practices might result in social discontent. There are known examples of social protests associated with the application of sewage sludge in agricultural practices. Similarly, the agricultural utilisation of mixture of sewage sludge and biomass ash might meet with social disapproval. For this reason, one of most important steps before the implementation of new solution on an industrial scale is the environmental education.

W2 high profitability of investment for treatment plants located near power plants: As previously mentioned, the cost of the application of biomass ashes in treatment plants is limited to the transport cost. For this reason, the whole investment is particularly profitable for treatment plants located near power plants. Even despite the long distance between treatment plant and power plant, the replacement of chemical reagent with the use of biomass ashes could decrease the operating costs of treatment plants in a significant way.

W3 increase the mass of sewage sludge as a result of the application of ashes: Similarly to the application of other chemical reagents, dosing of biomass ash into sewage sludge results in the increase of the volume of waste. According to Liu et al. [14], the total mass of generated sewage sludge containing BCBP might increase even by $30 \%$. However, the possibility to use of generated product in agricultural practices causes that the aforementioned weakness has secondary matters.

W4 necessity to buy new devices dedicated to dosing and storage of ash in sewage sludge treatment: The implementation of sewage sludge processing technology with the use of biomass ashes demands the small modernization of treatment plants. In costeffectiveness analysis, it is necessary to include additional cost associated with the acquisition of new devices for dosing and storage of ash, such as: silo, feeder and metering device of biomass ash. However, this cost will occur in the first year of investment.

W5 \& W6 requirements associated with the content of heavy metals and microorganisms in the mixture of sludge and ash before the application in the environment: Both sewage sludge and biomass ashes are waste product which might contain heavy metals. But research carried out by different authors proved that most of BCBP is characterized by the low concentration of heavy metals and meet requirements included in the Act of 10 July 2007 on Fertilizers and Fertilizers Application (Table 3) [15]. The influence of ashes on the reduction of microorganisms should also be assessed. Detailed tests should protect the environment against the contamination.

Table 3. Content of heavy metals in biomass ashes and in sludge according to different authors.

\begin{tabular}{|c|c|c|c|c|c|}
\hline \multirow{2}{*}{ Kind of biomass ash } & \multicolumn{5}{|c|}{ Content [mg/g dry mass] } \\
\cline { 2 - 6 } & $\mathrm{Fe}$ & $\mathrm{Cu}$ & $\mathrm{Cd}$ & $\mathrm{Hg}$ & $\mathrm{Pb}$ \\
\hline willow ash [5] & 114.2 & 2.8 & - & - & 1.5 \\
\hline ash from oak wood [12] & - & - & $7.8-29.0$ & 0.004 & $33.1-39.0$ \\
\hline ash from wheat straw [16] & 45.1 & 0.001 & - & - & - \\
\hline maximum content in line with [15] & - & - & 5.0 & 2.0 & 140.0 \\
\hline sewage sludge (own research) & - & 147.0 & 10.6 & 0.0 & 13.5 \\
\hline maximum content in line with [17] & - & 1000.0 & 20.0 & 16.0 & 750.0 \\
\hline
\end{tabular}




\subsection{Opportunities}

$01 \& 02$ soil quality improvement and reclamation of degraded lands after application of mixture of sludge and ash and the replacement of traditional fertilizers: As previously mentioned, the application of obtained mixture of sewage sludge and ash has a positive impact on the improvement of soil quality. Both sewage sludge and biomass ashes could contribute to the change of soil class in terms of the content of different elements, such as: $\mathrm{K}, \mathrm{Mg}$ or $\mathrm{Na}$. Additionally, the application of mixture of sewage sludge and biomass ash could recreate soil conditions and restore the balance between nutrients. Traditional fertilizing might be reduced or even eliminated by the use of aforementioned mixture.

03 \& 04 development of domestic biomass market and the improvement of energy security and supporting the requirements associated with EU climate and energy package (3 $x$ 20\%): Energy consumption is one of the main factors which stimulate social and economic development. For this reason, the energy demand is systematically growing. The new utilization method of combustion by-products could contribute to the popularization of biomass amongst renewable energy sources and the creating of local perennial plant's plantations. The development of biomass market might contribute to the achievement of $20 \%$ share of renewable energy sources in final energy production to 2020 .

\subsection{Threats}

T1 \& T2 afraid of treatment plants related with the implementation of new sludge treatment method and a small amount of experiments concerning the influence of biomass ash on the effectiveness of sewage sludge processing: Because the sewage sludge treatment with the use of biomass ashes is a new technology, this solution might meet with the disapproval of treatment plant's leadership. Additionally, the small amount of research concerning the influence of ashes on sewage sludge treatment might be a limiting factor.

\section{Strategies for promoting the use of biomass ashes in sewage sludge management}

Based on the presented SWOT analysis, strategies for the development of sewage sludge treatment with the use of biomass ashes could be proposed (Fig. 4). When establishing strategies, the principle "maximizing strengths and opportunities, transforming weaknesses to strengths and minimizing threats" should be applied.

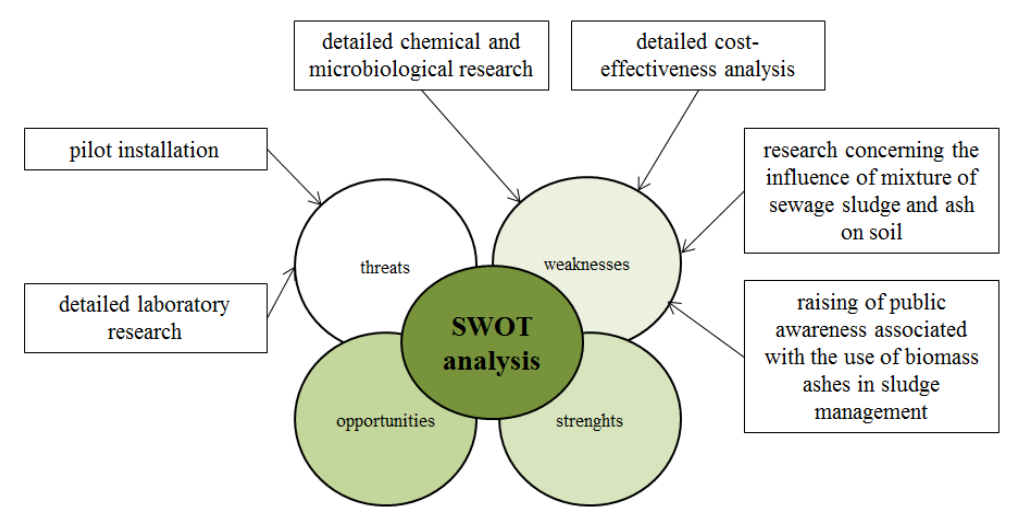

Fig. 4. Strategies for elimination of threats and weaknesses. 


\section{Summary}

Based on the aforementioned SWOT analysis, internal and external conditions of the application of biomass ashes in sewage sludge treatment were presented. The obtained results show that the aforementioned utilization of biomass ashes is a method for which strengths are dominant. The main advantages are the improvement of effectiveness of sludge processing and the reduction of biomass ashes landfilling. Furthermore, biomass ash is inexpensive, effective and easy-obtained reagent. In the meanwhile, such utilization of BCBP has some weaknesses concerning the content of heavy metals in ashes and associated with this social awareness of applying mixture of sludge and ash in agricultural practices.

In addition to that, the findings present some major opportunities, as well as the improvement of soil quality and the reclamation of degraded lands. Due to the content of nutrients in the mixture of sewage sludge and biomass ash, the aforementioned product might replace the use of traditional fertilizers. Additionally, the application of obtained mixture in perennial plants plantations contributes to the development of biomass market. In contrast, it is necessary to consider some threats associated mainly with the small amount of research concerning the use of biomass ashes in sewage sludge treatment.

Taking everything into consideration, the use of biomass combustion by-products in different steps of sludge treatment is the method for which advantages are dominant.

\section{References}

1. S.V. Vassilev, D. Baxter, L.K. Andersen, C.G. Vassileva, Fuel 105, 41 (2013)

2. E. Meller, E. Bilenda, Energy Policy Journal 15, 289 (2012)

3. M. Piekarczyk, D. Jaskulski, K. Kotwica, Fragm. Agron. 29, 129 (2012)

4. T. Ciesielczuk, G. Kusza, A. Nemś, Environmental Protection and Natural Resources 49, 221 (2011)

5. M. Wójcik, F. Stachowicz, A. Masłoń, E3S Web Conf. 17, 7 (2017)

6. M. Wójcik, F. Stachowicz, A. Masłoń, Engineering and Protection of Environment 20, 153 (2017)

7. PN-EN 197-1:2012, Cement - Part 1: Composition, specifications and conformity criteria for common cements

8. PN-EN 450-1:2012, Fly Ash For Concrete - Part 1: Definition, specifications and conformity criteria

9. K. Rajczyk, E. Giergiczny, M. Szota, Scientific Works of Institute of Ceramics and Building Materials 6, 73 (2013)

10. Z. Giergiczny, Budownictwo, Technologie, Architektura 3, 44 (2007)

11. A. Masłoń, Instal 4, 51 (2015)

12. M. Wójcik, F. Stachowicz, A. Masłoń, Engineering and Protection of Environment (to be published)

13. J. Kiper, JEE 18, 74 (2017)

14. H. Liu, S. Yang, J. Shi, X. Xu, B. Fu, Sep. Purif. Technol. 165, 53 (2016)

15. Act of 10 July 2007 on Fertilizers and Fertilization [J. of Laws No. 147, item. 1033]

16. [online] [access: 01.11.2017] https://powermeetings.eu/konferencje/prezentacje/FTEB 27-20-2011/21 R.Waclawowicz.pdf

17. Regulation of the Minister of the Environment dated 6th February 2015 on municipal sewage sludge [J. of Laws No. 2015, item 257] 